\title{
Dinamika Poligami di Tengah Budaya Oligarkis-Patriarkis (Studi pada Masyarakat Poliwali Mandar dan Konawe Sulawesi)
}

\author{
Anwar Sadat ${ }^{1}$ \\ Ipandang ${ }^{2}$ \\ ${ }^{1}$ STAIN Majene \\ Totoli, Banggae, Majene, Sulawesi Barat \\ ${ }^{2}$ IAIN Kendari \\ Jl. Sultan Qaimuddin No.17, Kendari, Sulawesi Tenggara \\ E-mail:anwarsadatstain@gmail.com
}

\begin{tabular}{llll}
\hline Submit & $: 08$ Maret 2020 & Diterima & $:$ 18 Mei 2020 \\
Revisi & $: 08$ April 2020 & Terbit & :03 Juni 2020 \\
\hline
\end{tabular}

\begin{abstract}
Abstraks: Artikel ini membahas sisi lain poligami dalam konteks hukum Islam di tengah budaya oligarkis-patriarkis. Selama ini, masyarakat ada yang menganggap realitas poligami sebagai tindakan yang lumrah dilakukan. Namun ada juga yang menyatakan bahwa sejatinya pernikahan perlu dipraktekkan dengan asas monogami. Karenanya, artikel ini fokus pada realitas poligami yang dialami oleh masyarakat kabupaten Poliwali Mandar Sulawesi Barat dan Kabupaten Konawe Sulawesi Tenggara berdasarkan narasi normatif. Kesimpulan dari artikel ini adalah realitas poligami muncul tidak lepas dari landasan nilai teologis dan budaya oligarkis-patriarkis. Oleh karenanya, intepretasi ayat sangat mempengaruhi pemikiran dan praktek pernikahan di suatu masyarakat. Seperti ungkapan satu saja ( $f a$ wăhidah) dalam QS. an-Nisa ayat 3 diintepretasikan bukan larangan berpoligami tetapi tuntutan untuk menikah (menambah) satu lagi selain istri pertama jika tidak mampu berbuat adil. Jika laki-laki mampu untuk berlaku adil pada dimensi materi, maka ia diperkenakan untuk menikah dengan empat perempuan sekaligus.
\end{abstract}

Kata kunci: Poligami, Budaya, dan Islam

Abstracts: This article attempts to look at the other side of polygamy in the context of Islamic law amid oligarchic-patriarchal culture. During this time, there are people who think the reality of polygamy as a normal action performed. But there are some stated that marriage should be practiced with the true principles of monogamy. Therefore, the article focuses on the wisdom of the polygamy reality experienced by the people of Polewali Mandar district in West Sulawesi and Konawe in Southeast Sulawesi based on normative narratives. The conclusion of this article is the reality of polygamy appears inseparably from the theological and cultural foundation of value-patriarchal oligarchic. Hence, the Quranic verse interpretation greatly influences the thought and practice of marriage in a society. Like the one phrase (fa wähidah) in QS. an-Nisa verse 3 which is interpreted not to prohibit a polygamy but the demand to marry another wife besides the first wife if she is unable to be fair. If a man is able to be fair in the matter of material, then he is permitted to marry at least four women at the same time.

Keywords: Polygamy, Culture, and Islam 


\section{Pendahuluan}

Artikel ini mengkaji realitas poligami dalam Islam dengan memfokuskan pada dimensi laten yang menyertainya. Realitas poligami memang sering memunculkan reaksi pemikiran sangat plural dengan berbagai latar kajian dan konklusi berbeda-beda. Seperti riset Hikmah yang menyimpulkan, praktek poligami memiliki dampak destruktif daripada yang konsruktif; ${ }^{1}$ riset Mukri mengajukan suatu pernyataan bahwa nas al-Qur'an tentang poligami tidak hanya tentang jumlah istri tetapi merupakan kritik atas kesewanang-wenangan pelampiasan nafsu. ${ }^{2}$ Riset Yusefri mengurai pemikiran poligami menurut Siti Musdah Mulia yang kontroversial-sebab realitas poligami diklaim haram lighairihi; ${ }^{3}$ ada pula riset yang melihat realitas poligami dari aspek intepretatif ayat, seperti riset Hendri, ${ }^{4}$ riset Moqsith ${ }^{5}$ atau riset Siti Asiyah, dkk. ${ }^{6}$ Bahkan ada pula yang menelisik pesan moralitas poligami dari sisi kehidupan nabi Muhammad seperti riset Ambar; ${ }^{7}$ serta ditelusuri pula hadis-hadis tentang poligami dari realitas sejarah dan kebahasaannya, sebagaimana riset Rohmansyah. ${ }^{8}$ Hal ini membuktikan bahwa realitas poligami perlu diurai seluk beluk geneologis yang mengitarinya termasuk hikmah laten yang ada di dalamnya.

Namun, ada sebagian perempuan non muslim atau pun yang beragama Islam ditengah masyarakat menganggap poligami melanggar hak asasi manusia terutama hak-hak kaum perempuan. Riset Thobejane \& Flora dalam kesimpulannya secara tegas menyatakan, praktek poligami menyebabkan kerugian bagi pihak perempuan, jika dibandingkan dengan praktek monogami. ${ }^{9}$ Bahkan dalam riset Yilmaz \& Tamam dalam kesimpulan tegas menyatakan bahwa perlu ada peningkatan kesadaran relasi poligami dengan gangguan kejiwaan; ${ }^{10}$ serta berdampak luas terhadap sosial dan ekonomi keluarga, sebagaimana kesimpulan dalam riset Dissa. ${ }^{11}$ Berdasarkan pada kajian-kajian yang hasilnya memposisikan pihak perempuan pada posisi subordinat memunculkan anggapan jika praktek tersebut memang tidak memihak perempuan. Dalam riset Ibiloglu, dkk. ditemukan bahwa pada konteks poligami, rasa kekhawatiran, ketakutan, dan kecemasan perempuan lebih tinggi daripada konteks monogami; ${ }^{12}$ seringkali pula perempuan yang menjadi istri pertama harga dirinya direndahkan, sebagaimana yang disimpulkan pada riset al-Krenawi. ${ }^{13}$ Karenanya, di Indonesia pola

\footnotetext{
Siti Hikmah, "Fakta Poligami Sebagai Bentuk Kekerasan Terhadap Perempuan," Sawwa:Jurnal Studi Gender 7, no. 2 (2012): 1-20. Moh Mukri, “Poligami: Antara Teks Dan Konteks Sosial,” Al-'Adalah 14, no. 1 (2017): 201-24.

Mukri.

4 Ali Hendri, “Poligami Perspektif Kitab Al-Tafsir Al-Wasit Li Al-Qur'an Al-Karim,” Al-Bayan:Jurnal Studi Al-Qur'an Dan Tafsir 3, no. 1 (2018): 51-61.

Abd. Moqsith, “Tafsir Atas Poligami Dalam Al-Qur'an,” Karsa: Journal of Social and Islamic Culture 23, no. 1 (2015): 133-49.

6 Siti Asiyah and et.al, "Konsep Poligami Dalam Al-Qur'an: Studi Tafsir Al-Misbah Karya M. Quraish Shihab," Fikri: Jurnal Kajian Agama, Sosial Dan Budaya 4, no. 1 (2019): 85-100.

Iriani Ambar, "Menelisik Pesan Moral Di Balik Poligami: Deskripsi Historis Kehidupan Muhammad SAW Dan Implikasinya Dalam Islam.," Jurnal Al-Maiyyah 8, no. 1 (2015): 120-34.

8 Rohmansyah, “Analisa Pendekatan Bahasa Dan Historis Terhadap Poligami Dalam Hadist Nabi.," Kalimah: Jurnal Studi Agama Dan Pemikiran Islam 17, no. 1 (2019): 55-70.

9 Tsoaledi Daniel Thobejane \& Takayindisa Flora, "An Exploration of Polygamous Marriages: A Worldview," Mediterranean Journal of Social Sciences 5, no. 27 (2014): 1058-66.

10 Ertan Yilmaz \& Lut Tamam, "The Relationship Between Polygamy and Psychiatric Disorder in Turkish Women," International Journal of Social Psychiatry 64, no. 8 (2018): 821-27.

11 Yaya Dissa, "Polygamy in Mali: Social and Economic Implications on Families," International Journal of African and Asian Studies 27, no. 1 (2016): 94-107.

12 Dissa.

13 Alean al-Krenawi, "Women of Polygamous Marriages in Primary Health Care Centers," Contemporary Family Therapy 21, no. 3 (1999): 417-30.
} 
poligami di atur oleh perundang-undangan -yaitu Undang-Undang Nomor 1 Tahun 1974 tentang Perkawinan dan Kompilasi Hukum Islam (KHI). ${ }^{14}$

Walaupun demikian, tidak sedikit ada kalangan perempuan Islam maupun non Islam mempunyai kesimpulan bahwa praktek poligami menurut Islamyang palingbaik dan manusiawi. Hasil riset Alamgir menyatakan bahwa poligami dalam Islam lebih memihak perempuan dan melindungi mereka dari degradasi sosial dan nilai-nilai moral yang rendah. ${ }^{15}$ Riset Batagarawa \& Yahaya menyimpulkan jika poligami yang dipraktekan dalam Islam sangat sesuai dengan kodrat diri manusia yang di dalamnya mengandung kebijaksanaan. ${ }^{16}$ Anggapan-anggapan negatif tersebut muncul dikarenakan adanya beberapa aspek, yaitu: pertama, kesalahan memahami poligami Nabi Muhammad; kedua, kesalahan memahami ayat-ayat poligami; ketiga, kesalahan dalam mendefinisikan poligami; dan keempat, kesalahan pria melakukan poligami, demikian kesimpulan riset Ahmad. ${ }^{17}$ Disinyalir juga dalam riset Sunaryo, kontroversi ini muncul disebabkan oleh tiga motif, yaitu: pertama, problem intepretasi teksteks keagamaan; kedua, perbedaan perspektif ketika melihat peran dan fungsi gender di masyarakat; dan ketiga, minimnya kesadaran dan kepatuhan terhadap aturan-aturan hukum di masyarakat. ${ }^{18}$

Kenyataannya, masyarakat yang memiliki budaya oligarki-patriarkis seperti di kabupaten Poliwali Mandar Sulawesi Barat dan Kabupaten Konawe Sulawesi Tenggara -selanjutnya ditulis KPMSB dan KKST- memiliki pola yang sangat adaptif dan konstruktif. Artinya, mereka relatif cenderung adaptif terhadap doktrin Islam tentang poligami melalui tindakan-tindakan konstruktifyang lazim dikatakan sebagai amal shaleh. Tampak dengan jelas, sesungguhnya poligami Islam yang dipraktekan mampu untuk melindungi, mengasihi dan mengangkat martabat perempuan. Bahkan para laki-laki masyarakat tersebut membiayai kehidupan para perempuan secara totalitas meliputi pembiayaan sandang, papan, dan pangan. Dari fenomena ini jelas bahwa poligami Islam jauh lebih bermartabat dibandingkan sistem poligami Barat; di mana setiap lelaki dengan mudah dapat menyeret perempuan hanya semata-mata untuk melampiaskan libido seksualnya. Tragisnya setelah ia terpuaskan libidonya, maka perempuan tersebut akan dilempar di pinggir jalan. ${ }^{19}$ Oleh sebab itu, dalam riset Mukri disimpulkan bahwa poligami tidak hanya semata-mata urusan libido, tetapi asas keadilan yang sangat sulit diwujudkan. ${ }^{20}$

Pada konteks tersebut, jelasnya realitas poligami mempunyai makna laten yang berupa hikmah atas kehidupan perempuan. Hal ini diakui oleh masyarakat KPMSB dan KKST. Pro-kontra ini mengukuhkan kesimpulan riset Sa'adah, dkk., pembahasan poligami masih sangat terbuka karena selama manusia memiliki orientasi pemikiran, rasa, dan perilaku yang berbeda, masalah poligami tidak akan pernah ada kesepakatan. ${ }^{21}$ Artinya, realitas poligami sebagai suatu diskursus yang berada

14 Fatimah Zuhrah, "Problems of Polygamy in Indonesia: Analysis of Law No. 1 of 1974 and KHI," Journal of Islam and Scince 5, no. 1 (2016): 1-17.

15 Aurangzaib Alamgir, "Islam and Polygamy: A Case Study in Malaysia," Procedia: Social and Behavioral Sciences 114, no. 1 (2014): 889-93.

16 Khadijah Tukur Batagarawa \& Atiku Garba Yahaya, "Counting Blessings with Cautions: Wisdom and Vitality of Polygamy in Islam," IOSR: Journal of Humanities and Social Science 23, no. 9 (2018): 47-53.

17 Wahid Syarifuddin Ahmad, "Status Poligami Dalam Hukum Islam: Telaah Atas Berbagai Kesalahan Memahami Nas Dan Praktik Poligami," Al-Ahwal: Jurnal Hukum Keluarga Islam 6, no. 1 (2013): 57-70.

18 Agus Sunaryo, "Poligami Di Indonesia: Sebuah Analisis Normatif-Sosiologis," Yin Yang: Jurnal Studi Gender \& Anak 5, no. 1 (2010): 143-67.

19 Abduttawab Haikal, Rahasia Perkawinan Rasulullah SAW: Poligami Dalam Islam vs Monogami Barat, ed. Ilyas Isma'il al-Sendany (Jakarta: CV. Pedoman Ilmu Jaya, 1993).

20 Mukri, "Poligami: Antara Teks Dan Konteks Sosial."

${ }^{21}$ Nuru Sa'adah and et.al, "Poligami Dalam Lintas Budaya Dan Agama: Meta-Interpretation Approach," Asy-Syir'ah: Jurnal Ilmu 
di tengah masyarakat terutama di budaya oligarki-patriarki senantiasa menarik untuk ditelaah dimensi latennya. Dimensi yang dimaksud dalam konteks ini adalah makna yang tersembunyi dan bersifat personal dirasakan oleh masyarakat. Berdasarkan pada konteks tersebut, artikel ini mencoba untuk mengurai dimensi laten dari realitas poligami yang dipraktekkan oleh masyarakat KPMSB dan KKST. Oleh sebab itu, fokus artikel ini pada hikmah yang ada dalam realitas poligami dan dialami oleh masyarakat (konteks) berdasarkan narasi normatif.

\section{Poligami dalam Tinjauan Narasi Wahyu dan Masyarakat}

Dalam al-Qur'an terdapat dua ayat yang menjelaskan tentang poligami dengan batasan dan syarat yang harus diikuti, yakni pada QS. an-Nisa' ayat 3 dan 129. Dari deskripsi dua ayat tersebut disimpulkan, Islam hanya "membolehkan" poligami (beristri lebih dari satu dalam waktu yang bersamaan), bukan diwajibkan maupun disunnahkan. Artinya, realitas poligami memiliki hukum kepastian yang menuntun pada sikap memilih untuk melakukannya. Marzuki dalam kesimpulan risetnya menekankan bahwa poligami bisa dilakukan senyampang tidak melepaskan nilai-nilai konstruktif yaitu kemaslahatan umat. ${ }^{22}$ Karenanya, dalam riset Mustofa dikatakan bahwa poligami pada dasarnya dilakukan untuk melindungi perempuan; ${ }^{23}$ bahkan lebih spesifik dalam riset Makrum dijelaskan jika poligami dimaksudkan sebagai bentuk solusi untuk menghindari kezaliman kepada anak yatim perempuan. ${ }^{24}$

Memang pada dasarnya prinsip pernikahan dalam Islam adalah monogami, sehinggajika akhirnya poligami diperbolehkan itu bukan berarti Islamlah yang pertama kali memperbolehkannya. Poligami telah muncul dan memasyarakat pada bangsa-bangsa dan agama-agama terdahulu sebelum Islam lahir. Fakta sejarah memperlihatkan, jika bangsa Ibrani, Arab Jahiliyah, dan Cisilia yang melahirkan bangsa penghuni negara Rusia, Poland, dan Yugoslavia mempraktekkan poligami. Hasyim secara detail menjelaskan praktek poligami sebelum Islam telah memang telah dijadikan sebagai tradisi yang tidak terbantahkan. ${ }^{25}$ Namun ketika Islam datang praktek poligami tetap dilestarikan dengan memiliki nuansa-nuansa yang lebih humanis, egaliter, dan penuh nilai-nilai spiritual. Hal ini berarti, poligami dalam Islam tidak lepas dari etika kemanusiaan dan ketuhanan, sehingga ia hanya sebagai ajang pelampiasan libido.

Pembolehan poligami dalam Islam tersebut perlu pembingkaian sebagai realitas pengecualian (istišn $\bar{a}^{\prime}$ ) dibandingkan dengan konsep poligami lainnya. Artinya, konsep pengecualian dimaksudkan sebagai tindakan yang dapat dilakukan dalam keadaan terpaksa (darurat). Pada konteks inilah, masyarakat KPMSB dan KKST memahami pola dasar poligami sebagai tindakan alternatif solutif terhadap kondisi kemanusiaan kaum perempuan. Karenanya, mereka memaknai pintu darurat bisa dibuka berdasarkan bukti dan alasan yang kuat dan terikat dengan etika. Hal ini sesuai dengan kaidah ilmu Fikih yang memberikan hukum rukhșah (keringanan) untuk memakan daging babi (sekedar menghilangkan rasa lapar); terlebih lagi menyebabkan seseorang mati karena kelaparan.

Syari'ah Dan Hukum 49, no. 2 (2015): 479-99.

22 Marzuki, "Poligami Dalam Hukum Islam," Jurnal Civics: Media Kajian Kewarganegaraan 2, no. 2 (2005): 1-10.

23 Muhammad Arif Mustofa, "Poligami Dalam Hukum Agama Dan Negara," Al-Imarah:Jurnal Pemerintahan Dan Politik Islam 2, no. 1 (2005): 47-58.

24 Makrum, “Poligami Dalam Perspektif Al-Qur'an,” Maghza:Jurnal Ilmu Al-Qur'an Dan Tafsir 1, no. 2 (2016): 35-50.

25 Syafiq Hasyim, Hal-Hal Yang Tak Terpikirkan Tentang Isu-Isu Keperempuanan Dalam Islam: Sebuah Dokumentasi (Bandung: Mizan, 2001). 
Kebijaksanaan Islam ini hanyalah sebagai jalan keluar agar relasi laki-laki dan perempuan penuh dengan kemaslahatan dan mendamaikan. Karenanya, salah satu ulama' besar yaitu M. Quraish Shihab menyatakan bahwa poligami hanya merupakan pintu darurat. ${ }^{26}$

Pernikahan adalah sesuatu yang sangat prinsipil dan sangat dihargai dalam Islam, serta ia merupakan bentuk perlindungan dan penumbuhan potensi perempuan. ${ }^{27}$ Melalui lembaga pernikahan yang sah inilah kebutuhan biologis dan keinginan seksual dapat tersalur dengan baik dan aman. Masyarakat KPMSB dan KKST sendiri mengakui peran pernikahan terhadap aspek biologis dan psikologis yang sangat signifikan. Walaupun di satu sisi, masyarakat KPMSB dan KKST ada juga yang mempunyai asumsi bahwa poligami sejatinya merupakan ajang "pelampiasan" libido laki-laki. Bahkan ada dari mereka yang secara ekstrim menyatakan kalau poligami bisa dijadikan topeng legal pelampiasan libido laki-laki. Akan tetapi, mayoritas penduduk Indonesia mempunyai penafsiran yang berbeda-beda, antara lain: ada yang akomodatif (aliran tekstualis), tidak menerima atau menolak (semi-tekstualis), dan menolak (kontekstualis), seperti yang dibahas dalam riset Nurmila. ${ }^{28}$

Memang perlu diakui, pada zaman Jahiliyah sebelum Islam datang, penduduk Jazirah Arab melakukan poligami tanpa batas aturan sekedar memenuhi kepuasan seksual laki-laki. ${ }^{29}$ Pada saat Islam datang poligami diluruskan agar memuat nilai-nilai kemanusiaan, sehingga ia diperbolehkan mengingat banyaknya janda-janda dan anak-anak gadis yatim piatu yang perlu diselamatkan moralnya. Masyarakat KPMSB dan KKST sendiri sadar jika poligami perlu diarahkan pada nilai-nilai kemanusiaan, bukan hanya memuat nilai-nilai biologis semata. Karenanya, pada penafsiran tentang istimbat hukum poligami menggunakan metode mașlahah mursalah, ${ }^{30}$ agar nuansa perlindungan terhadap nilai-nilai kemanusiaan lebih terbuka lebar. Sehingga poligami tidak hanya bernuansa biologis semata, tetapi juga akan bermakna sosiologis dan sekaligus teologis. Pada konteks inilah, masyarakat KPMSB dan KKST memaknai poligami berdasarkan nilai-nilai kemanusiaan sebagaimana yang diisyaratkan dalam Islam.

Karenanya, masyarakat KPMSB dan KKST sendiri sangat berharap bahwa poligami bisa menjadi ajang mendapatkan kebahagiaan hakiki. Kebahagiaan ini salah satunya bisa diperoleh melalui pernikahan yang dianugerahi keturunan. Oleh sebab itu, tanpa keturunan sebuah rumah tangga akan jauh dari kebahagiaan, sehingga melalui realitas poligami dapat diposisikan sebagai alternatif-solutif. Pola ini selaras dengan kesimpulan riset Riyandi bahwa poligami dapat diwujudkan dengan pertimbangan argumentatif untuk melindungi -baca memelihara- agama, akal, keturunan, kehormatan, dan harta (maqasid syar'iyyah). ${ }^{31}$ Karenanya, Masyarakat KPMSB dan KKST sendiri cenderung bersikap terbuka terhadap realitas poligami yang secara sosiologis -maupun dengan tafsiran doktrin keislaman tentang poligami- memiliki kesesuaian dengan keadaan masyarakat. Di mana masyarakat oligarkis-patriarkis tersebut cenderung mengedepankan dominasi elit lakilaki terhadap diri perempuan dalam bentuk budaya yang dilegitimasi nilai keagamaan. Karenanya,

${ }^{26}$ Quraish Shihab, Wawasan Al-Qur'an: Tafsir Maudhu’i Atas Pelbagai Persoalan Umat (Bandung: Mizan, 2004).

27 Abu Ameenah Bilal Philips \& Jamila Jones, Polygamy in Islam (Riyadh: International Islamic Publishing House, 1994).

28 Nina Nurmila, Women, Islam and Everyday Life: Renegotiating Polygamy in Indonesia (London: Routledge, 2009).

29 Jawwad Ali, Sejarah Arab Sebelum Islam: Kondisi Sosial-Budaya, ed. M. Yusni Amru \& Moh. Ali, 4th ed. (Jakarta: Alvabet, 2019).

30 Mahridha, "Poligami Dalam Kajian Hukum Islam: Studi Analisis Pandangan Hasbi Ash-Shiddiegy," Jurisprudensi: Jurnal Ilmu Syari'ah, Perundang-Undangan Dan Ekonomi Islam 9, no. 2 (2017): 50-78.

31 Riyandi S, "Syarat Adanya Persetujuan Istri Untuk Berpoligami: Analisis Fikih Syafi'iyyah Terhadap Undang-Undang Perkawinan Nomor 1 Tahun 1974," Jurnal Ilmiah Islam Futura 15, no. 1 (2015): 111-42. 
pada masyarakat ini mayoritas para elit masyarakat seperti pejabat maupun orang kaya melakukan pernikahan poligami.

Bahkan salah satu tokoh Masyarakat KPMSB dan KKST yang juga bagian dari elit masyarakat memberikan argumentasi bahwa sejatinya poligami mampu mencegah perbuatan zina. Masyarakat tersebut juga mempunyai pandangan untuk terus menjauhi tindakan yang dialarang oleh Islam seperti zina tersebut -QS. al-Israa' ayat 32. Lazim jika tindakan poligami menjadi pintu alternatif untuk menjauhi masyarakat dari perbuatan keji (zina). Perbuatan ini kemungkinan besar dilakukan oleh para wanita yang belum atau tidak mempunyai suami serta janda dan anak yatim piatu yang ditinggal mati suami mereka. Dalam riset Hendri yang fokus kajiannya pada kitab al-Tafsir al-Wasit Li al-Qur'an al-Karim menyimpulkan bahwa untuk menghindari zina masyarakat boleh melakukan praktek poligami. ${ }^{32}$ Jelasnya poligami sejatinya memberikan perlindungan terhadap komunitas perempuan yang memerlukan kesejahteraan hidup dan kelayakan kehidupan dari seseorang lakilaki. Maka Islam memberikan jalan keluar yang terbaik melalui realitas poligami yang memiliki nilainilai kemanusiaan luhur dan suci. Landasan keadilan yang termuat didalamnya menjadi patokan utama dan secara eksplisit dijelaskan dalam QS. an-Nisa' ayat 3 bahwa: “Dan apabila kamu takut tidak berbuat adil terhadap perempuan yatim (yang kamu kawini) maka kawinilah wanita-wanita lain yang kamu senangi dua, tiga atau empat, tapi jika kamu takut tidak berlaku adil maka kawinilah seorang saja".

Ayat tersebut oleh Masyarakat KPMSB dan KKST diposisikan menjadi standar utama dalam mengurai makna tindakan poligami. Mereka berasumsi, ayat tersebut sudah sangat jelas menerangkan agar masyarakat untuk berpoligami atas dasar asas keadilan. Artinya, Masyarakat KPMSB dan KKST sadar jika yang diperbolehkan untuk melakukan poligami hanya bagi mereka yang mempunyai kesanggupan untuk berbuat adil. Pengecualian terhadap "adil” inilah senantiasa menghiasi diskursus poligami di tengah-tengah Masyarakat KPMSB dan KKST. Tokoh Masyarakat KPMSB dan KKST pun memberikan penegasan jika makna adil yang dimaksud terletak pada persoalan yang hanya bisa dilakukan oleh kadar kemanusiaan masyarakat, seperti pemberian rumah dan pembagian waktu yang sama, pakaian serta nafkah lahir batin. Di dalam istilah peneliti, hal tersebut yang dimaksud dengan keadilan kuantitatif dan sifatnya manifes Sementara keadilan yang bersifat kualitatif, tokoh Masyarakat KPMSB dan KKST mencontohkan pada pembagian perasaan cinta dan kasih sayang merupakan di luar kemampuan manusia. Karenanya, realitas tersebut tidak bisa lepas dari otonomi Allah untuk menetukan tinggi-rendah dan besar-kecilnya kadar cinta dan perasaan kasih sayang sosok laki-laki terhadap perempuan.

Pada konteks tersebut, keadilan yang bersifat "maknawi" berupa getaran jiwa (emosi) seperti perasaan cinta, rindu dan benci tidak semua orang akan mampu mengendalikannya. Tokoh Masyarakat KPMSB dan KKST tegas menafsirkan bahwa manusia tidak akan mampu membagi cinta secara adil dan merata kepada semua istri, anak-anak maupun untuk semua temannya. Rasulullah SAW sendiri mengakui ketidaksanggupannya membagi cinta secara adil dan merata di antara istriistri dirinya ketika berpoligami pasca penikahan dengan Khadijah. Cinta nabi Muhammad lebih cenderung kepada Aisyah, karena itu ia mengajukan alasannya kepada Allah dalam sebuah do'anya, bahwa: "Ya Allah... Aku telah berbuat adil dalam segala hal yang aku miliki namun jangan Engkau hina diriku dalam hal yang merupakan milik-Mu dan bukan milikku" (HR. Abu Daud, Turmudzy dan Nasa'i). ${ }^{33}$ Oleh

\footnotetext{
32 Hendri, "Poligami Perspektif Kitab Al-Tafsir Al-Wasit Li Al-Qur'an Al-Karim."

33 Abu Isa Muhammad bin Saurah al-Tirmidzi, Sunan Al-Tirmidzi (Beirut: Dar al-Fikir, 1980).
} 
karenanya, dalam riset Khoiriah dinyatakan bahwa nabi Muhammad lebih cenderung pada konsep humanis dalam berpoligami. ${ }^{34}$

Walaupun demikian, Masyarakat KPMSB dan KKST ketika melakukan poligami tidak "terbatas" dan "asal”. Mereka kuat memegang makna kandungan QS. an-Nisa' ayat 3 tersebut, sehingga muncul pemahaman "seorang laki-laki boleh memiliki istri lebih dari satu dalam waktu yang bersamaan asal saja tidak melebihi dari empat istri”. Jelasnya, narasi poligami yang muncul di tengah Masyarakat KPMSB dan KKST tidak lepas dari basis kemanusiaan dan etika. Kondisi ini selaras dengan nilai historis yang terjadi pada era nabi Muhammad. Ketika Ghailan al-Tsaqafi telah masuk Islam dan ia memiliki sepuluh orang istri. Kondisi ini disampaikan kepada nabi Muhammad dan nabi pun bersabda, bahwa: "pilihlah empat dari mereka istri-istrimu dan ceraikanlah yang selebihnya". ${ }^{35}$

Dari deskripsi tersebut jelas jika Masyarakat KPMSB dan KKST secara normatif menganggap lembaga pernikahan bernuansa poligami merupakan suatu kewajaran di atas kedaruratan. Artinya, lembaga sosial tersebut dianggap hanya bisa diisi oleh satu suami atau satu istri; walaupun mereka tidak "alergi" terhadap pola dan nilai-nilai poligami. Melalui sikap penerimaan ini, para elit masyarakat KPMSB dan KKST lebih cenderung memilih pernikahan poligami yang akhirnya dianggap sebagai ketetapan budaya dengan legitimasi interpretasi doktrin-doktrin keagamaan Islam.

Uniknya pula, mereka juga memiliki pengetahuan yang relatif luas terkait perundang-undangan konvensional tentang perkawinan -seperti Undang-Undang No. 1 Tahun 1974 Tentang Perkawinan atau Undang-Undang No. 16 Tahun 2019 Tentang Perubahan atas UU No. 1 Tahun 1974- maupun undang-undang syari'ah -baca Kompilasi Hukum Islam (KHI). Kedua undang-undang tersebut menganut sistim monogami dan Masyarakat KPMSB dan KKST sendiri memahami aturan-aturan tersebut. Namun, mereka juga sadar jika Islam membuka pintu tindak poligami atas dasar darurat untuk membolehkan seorang laki-laki beristri lebih dari satu. Bahkan ditambah syarat, laki-laki yang memilih berpoligami harus bertanggung jawab penuh dan berlaku adil terhadap semua istri. Atas dasar prinsip ini, masyarakat KPMSB dan KKST menerima pola budaya oligarkis-patriarkis dalam bentuk praktek pernikahan poligami.

Fenomena pernikahan poligami oleh masyarakat KPMSB dan KKST telah dianggap kelaziman, akan tetapi ia akan retak dan pecah pada saat sang suami menunjukkan ketidakadilan -hal inilah yang menjadi dasar utama perceraian. Jawaban para istri terhadap pertanyaan peneliti bahwa ketika suami melakukan peligami dan bersikap tidak adil, maka rumah tangga akan menghadapi masalah yang krusial. Maksudnya adalah setiap pelaku poligami perlu mengedepankan sikap dan tindakan adil sebagai asas bangunan rumah tangga poligami. sehingga, banyak rumah tangga poligami khususnya rumah tangga para elit masyarakat- yang berakhir perceraian dikarenakan sikap dan tindakan suami yang tidak adil.

Masyarakat KPMSB dan KKST juga sadar jika mereka khawatir tidak bisa berlaku adil, maka dirinya tidak akan memilih untuk poligami; atau bahkan tokoh agama Masyarakat KPMSB dan KKST melarang nikah lebih dari satu. Salah satu tokoh keagamaan menyatakan bahwa jika ada laki-laki beristri lebih dari satu dan ia lebih mementingkan salah satu diantara mereka, maka ia telah berlaku dzalim dan tidak berperikemanusiaan. Seakan-akan ada fatwa yang muncul di masyarakat KPMSB dan KKST tersebut (yaitu masyarakat oligarkis-patriarkis) bahwa beristri lebih dari satu dengan

\footnotetext{
34 Rike Luluk Khoiriah, "Poligami Nabi Muhmmad Menjadi Alasan Legitimasi Bagi Umatnya Serta Tanggapannya Kaum Orientalis," Jurnal Living Hadis 3, no. 1 (2018): 1-21.

35 Abdullah Nashih Ulwan, Bahagia Nabi Bersama Istri-Istrinya (Yogyakarta: Absolut, 2002).
} 
berlaku adil sangat dibolehkan, tetapi beristri lebih dari empat haram. Namun yang paling halal adalah beristri cukup satu.

\section{Dasar Hukum Poligami: Antara Islam dan Budaya}

Masyarakat KPMSB dan KKST merupakan masyarakat yang relatif unik yang bercirikhaskan pada karakteristik kedaerahan. Di mana Masyarakat KPMSB lebih menekankan pada keharmonisan substantif, sedangkan Masyarakat KKST memiliki orientasi pada kebahagiaan yang hakiki. Oleh karenanya, secara kuantitatif antara kedua masyarakat tersebut juga memiliki pola kehidupan -baca tradisi dan budaya- yang berbeda. Walaupun ada ruang-ruang perbedaan antara Masyarakat KPMSB dan KKST, namun antara keduanya memiliki kesamaan dalam memposisikan dasar hukum poligami. Masyarakat tersebut merupakan masyarakat yang memposisikan para elit masyarakat berjenis kelamin laki-laki di atas "kekuatan" perempuan, sehingga budaya yang dianut kedua masyarakat tersebut bersifat oligarkis-patriarkis. Apalagi suku Mandar yang terkenal sebagai pelaut yang tangguh dan sangat ulung; ${ }^{36}$ wajar apabila di perahu mereka seperti perahu sandeq dan roppo sarat dengan simbol-simbol kebijaksanaan; ${ }^{37}$-termasuk dalam kosmologi laut. ${ }^{38}$

Di dalam wacana pernikahan pun, Masyarakat KPMSB dan KKST mempunyai ketaatan tinggi terhadap doktrin-doktrin keagamaan. Mereka tanpa ragu yang berdasar pada penggunaan nalar kritis memposisikan hukum pernikahan tidak lepas dari al-Qur'an dan Hadis. Kedua sumber ini diyakini memuat segala ketentuan Tuhan secara rinci dan detail tentang realitas penikahan poligami. Adapun persoalan baru yang muncul dan tidak mendapatkan kepastian hukum dalam al-Qur'an dan Hadis, maka Masyarakat KPMSB dan KKST menggunakan ijtihad penentuan hukum yang dilakukan oleh para ulama'. Akan tetapi, mereka cenderung menggunakan ijitihad ulama' yang terancang berdasarkan hasil kesepakatan ulama' (Ijma'). Ijma' pada konteks ini diposisikan sebagai sumber hukum penikahan pula setelah al-Qur'an dan Hadis. Namun menariknya, Masyarakat KPMSB dan KKST masih mempertimbangkan dimensi budaya mereka sebagai pertimbangan keabsahan lainnya.

Masyarakat KPMSB dan KKST memahami bahwa ketetapan hukum "boleh" melakukan tindak poligami terdapat dalam dua ayat pada QS. an-Nisa ayat 3 dan 129. Pada QS. an-Nisa' ayat 3 diterangkan bahwa "jika seseorang takut tidak berbuat adil terhadap perempuan yatim bila hendak mengawininya, maka hendaknya agar mengawini perempuan yang disenangi bisa berjumlah dua, tiga atau empat. Akan tetapi, apabila takut tidak berbuat adil cukup mengawini mereka satu saja atau budak-budak yang dimilikinya". Memahami pesan suci ini, Masyarakat KPMSB dan KKST tidak serta merta melakukan tindakan poligami dalam pernikahannya; terlebih jika didasarkan pada pertimbangan biologis. Mereka secara tegas dan meyakinkan menyatakan bahwa ayat ini menunjukan Islam tidak melarang melakukan poligami berdasarkan nilai-nilai kemansiaan terutama asas keadilan. Oleh sebab itulah, ada sebagaian dari mereka cenderung ingin meluruskan dan memberi batasan poligami yang sudah berkembang di Masyarakat KPMSB dan KKST dengan corak oligarkis-patriarkis. Hal ini tidak lepas dari alur sejarah yaitu ketika penaklukan penjajahan menciptakan perubahan bisnis administratif terutama di masyarakat Mandar menjadi sistem kekaisaran. ${ }^{39}$

36 Christian Pelras, Manusia Bugis (Jakarta: Nalar, 2006).

37 Rarasrum Dyah Kasitowati, "Sandeq Dan Roppo: Kearifan Lokal Suku Mandar Pesisir, Sulawesi Barat," Sabda: Jurnal Kajian Kebudayaan 6, no. 1 (2011): 63-68.

38 Sastri Sunarti, “Kosmologi Laut Dalam Tradisi Lisan Orang Mandar Di Sulawesi Barat," Aksara 29, no. 1 (2017): 33-48.

39 Abd. Karim, “Sibali Parri: Andi Depu Dalam Gerakan Revolusi Di Mandar 1942-1946," Tebar Science: Jurnal Kajian Sosial \& Budaya 2, no. 2 (2018): 15-27. 
Menariknya, ada kalangan dari masyarakat KKST yang mengajukan sebuah pertanyaan "menggelitik" tentang keberadaan QS. an-Nisa ayat 3 tersebut. Mereka menyatakan, mengapa Allah langsung menawarkan dua (matsna), tiga (tsulasa), empat ( $r u b a^{\prime}$ ) dan tidak mengawali dengan kuantitatif satu (wahid). Tokoh agama masyarakat KKST seringkali memberikan penafsiran bahwa ayat ini memang suatu "petunjuk" poligami, sehingga hasil akhirnya meskipun menyebut jumlah satu (wahida) tetap ia merujuk pada realitas poligami. Bahkan ia juga menambahkan, ungkapan satu saja ( $f a$ wahida) bukan merujuk pada istri pertama melainkan tuntunan untuk menambah satu saja. Lazim jika masyarakat KKST mempunyai kesimpulan, kalau makna "satu saja" (fa wahida) dimaknai sebagai bentuk kebolehan menambah satu orang lagi di luar istri pertama jika tidak mampu berbuat adil.

Penafsiran tersebut tidak lepas dari konstruksi pengetahuan masyarakat KPMSB dan KKST yang muncul dari referensi mereka. Salah satu yang mereka sebutkan adalah Tafsir al-Kabir yang disusun oleh Muhammad ibn Umar Fakhr al-Din al-Razi; dan tafsir ini pun dianggap sebagai ensiklopedik yang memuat berbagai metode tafsir, yaitu: tafsir ra'yi, tafsir aśar, dan tafsir 'ilmi. Berdasarkan pada pandangan tafsir QS. an-Nisa' ayat 3, sebagian tokoh agama masyarakat memiliki pemahaman kata an-nis $\bar{a}$ ' bermakna umum yang tidak dispesifikasikan secara kuantitatif (dua, tiga, atau empat). Karenanya, elit masyarakat KPMSB dan KKST meyakini laki-laki boleh menikah poligami tanpa ada batasan kuantitas. Landasan utama keabsahan poligami menurut mereka adalah keadilan itu sendiri, namun masyarakat tetap memilih kuantitas poligami yang terbanyak adalah empat perempuan.

Sedangkan di satu sisi, budaya oligarkis-patriarkis di masyarakat tersebut ternyata mampu membangun pemahaman superior laki-laki terhadap diri perempuan. Pada konteks inilah akan terjadi pergeseran makna terhadap pernikahan yang hanya dibatasi oleh relasi seksualitas. Pun demikian seksualitas menjadi entitas tidak netral (memihak) disebabkan oleh dorongan-dorongan sistem yang mendominasi kehidupan perempuan. Oleh sebab itu, Masyarakat KPMSB dan KKST dalam budaya kesehariannya sangat mendominasi kehidupan perempuan. Dalam sistem budaya oligarkispatriarkis Masyarakat KPMSB dan KKST inilah poligami tumbuh subur. Nyatanya, seksualitas perempuan Masyarakat KPMSB dan KKST relatif dieksploitasi sedemikian rupa untuk kepentingan laki-laki yang cenderung terus menghegemoni. Posisional inilah yang turut berperan menggeser "kesejajaran" perempuan ke tempat yang lebih rendah dari laki-laki; bahkan menempatkan posisi perempuan sebagai "objek" seksualitas semata. Wajar jika perempuan di masyarakat tersebut seperti boneka bagi laki-laki yang perlu tampil sempurna tidak ada cacat sedikit pun untuk menjadi objek kepentingan diri laki-laki.

Namun, tidak semua Masyarakat KPMSB dan KKST melakukan tindakan poligami memiliki makna hegemonik. Ada sebagian yang melakukannya dengan asas kemanusiaan yang egaliter. Sebagian kalangan inilah terus menerus menerjemahkan nilai-nilai keagamaan seperti pesan-pesan keadilan dalam poligami. Pada QS. an-Nisa' ayat 129 sendiri memang telah dijelaskan bahwa "manusia sekali-sekali tidak akan dapat berbuat adil terhadap istri-istri mereka walaupun ia sangat ingin berbuat adil. Karenanya, ia memang terlalu cenderung kepada orang yang dicintainya dan membiarkan yang lain terkatungkatung". Wajar apabila para tokoh agama Masyarakat KPMSB dan KKST memberikan kerangka bahwa ayat ini menghendaki bahwa sosok suami perlu berusaha untuk berbuat adil terhadap istri-istrinya. Walaupun di sisi yang lain, Allah sendiri menyatakan bahwa mereka (para suami) tidak akan bisa berbuat adil walaupun mereka (suami) sangat ingin berbuat adil. Ibnu Hazm al-Zahiri, seperti dalam 
kesimpulan riset Hidayatulloh, menyatakan wajib untuk berlaku adil dalam pernikahan poligami. ${ }^{40}$ Karenanya, Mushthofa al-'Adawi seperti yang dilukiskan dalam riset Faisol memiliki pandangan, poligami merupakan tindakan pernikahan yang disunnahkan. ${ }^{41}$

Kalangan tersebut sadar jika adil yang dimaksud dalam QS. an-Nisa' ayat 129 merupakan bersifat khusus menyangkut perasaan cinta dan kasih sayang (al-hubb al-qalb) yang tentu saja tidak dapat dibagi-bagi. Dalam riset Azwarfajri dikatakan, keadilan yang bersifat immaerial memang sangat sulit diwujudkan, walaupun telah ada komitmen untuk menjaga kepercayaan masing-masing. ${ }^{42}$ Sedangkan larangan untuk tidak terlalu cenderung dipahami sebagai bentuk kecenderungan yang bisa dimaafkan, karena tidak ada yang bisa mengendalikan perasaan cinta, rindu dan benci. Masyarakat KPMSB dan KKST sangat paham pada batas kemampuan mereka sendiri -dalam hal ini para lakilaki yang poligami- dalam konteks berbuat adil. Akan tetapi, mereka sendiri mempunyai keinginan untuk menikah dengan pola poligami jika dimungkinkan mampu berlaku adil, egaliter, dan humanis. Tidak bisa dipungkiri, Masyarakat KPMSB dan KKST yang berbudaya oligarkis-patriarkis memang cenderung untuk berpoligami dengan argumentasi nilai-nilai keagamaan dan budaya.

Selain ayat-ayat al-Qur'an yang dijadikan sebagai kerangka legitimasi terhadap praktek poligami Masyarakat KPMSB dan KKST, ada pula hadis nabi Muhammad yang dijadikan dasar operasional. Hadis-hadis tersebut sejatinya menceritakan tentang para sahabat yang diperintahkan menceraian istri-istri mereka yang lebih dari empat. Mereka menganggap hadis-hadis ini sebagai landasan operasional yang membolehkan poligami sampai empat istri. Hadis-hadis yang dijadikan sadar, antara lain: pertama, hadis yang diriwayatkan oleh al-Tirmidzi bahwa "Hanad telah memberitahukan kami bahwa Abdullah memberitahukan kami katanya Said Bin Abi Urbah dari Ma'mar, dari Az Zurhi dari Salam Bin Abdullah dari Ibnu Umar bahwa Khailan Bin Salamah Al Tsaqufi telah masuk Islam bersama sepuluh istrinya pada masa jahiliyah. Kemudian Nabi menyuruhnya untuk memilih empat istri dan menceraikan lainnya". ${ }^{43}$ Dan hadis yang kedua, diriwayatkan oleh Imam Hanbal dalam kitab Sunan bahwa Qaid Ibnu Al Harits masuk Islam dan ia memiliki delapan orang istri. Akan tetapi, nabi Muhammad memerintahkan untuk memilih empat dari mereka. ${ }^{44}$ Dua hadis sahih inilah yang dijadikan dasar hukum operasional diperbolehnya pernikahan pola poligami, sehingga Masyarakat KPMSB dan KKST melalui budaya oligarkis-patriarkis mendapatkan pijakan kuat.

Berdasarkan fenomena tersebut dapat dikatakan realitas poligami merupakan bentuk pernikahan yang "eksis" di Masyarakat KPMSB dan KKST dan dinyatakan sesuai dengan doktrin Islam oleh para tokoh agama. Meski kelihatannya doktrin Islam membatasi jumlah perempuan yang boleh dinikahi ada empat, tetapi jumlah ini terkadan masih dilampui oleh Masyarakat KPMSB dan KKST sendiri. Ada pula yang memahami jumlah yang ditawarkan oleh doktrin Islam sebagai batas maksimal dikatakan jumlah yang terbilang "wah" -baca kuantitas yang banyak. Terlebih lagi untuk standar Masyarakat KPMSB dan KKST yang secara biologis-seksualitas tidak seperti mayoritas umat Islam bangsa Arab. Peneliti pada konteks ini memang punya keyakinan

\footnotetext{
40 Haris Hidayatulloh, “Adil Dalam Poligami Perspektif Ibnu Hazm,” Religi: Jurnal Studi Islam 6, no. 2 (2015): 207-36.

${ }^{41}$ Yufni Faisol, "Konsep Adil Dalam Poligami: Telaah Pemikiran Mushthofa Al-'Adawi Dalam Tafsir Al-Tashil Lita'Wil Al-Tanzil," International Journal Ihya' Ulum Al-Din 18, no. 1 (2016): 25-47.

42 Azwarfajri, “Keadilan Berpoligami Dalam Perspektif Psikologi,” Jurnal Substantia 13, no. 2 (2011): 161-71.

43 Abu Isa Muhammad bin Saurah al-Tirmidzi, Sunan Al-Tirmidzi.

44 Abu Isa Muhammad bin Saurah al-Tirmidzi.
} 
bahwa asas pernikahan dalam Islam adalah monogami; dan hal ini merupakan pilihan utama dan pertama. Akan tetapi, Islam tidak memberikan pilihan sama sekali selain poligami. Alternatif pola pernikahan ini yang oleh Masyarakat KPMSB dan KKST diyakini memiliki dimensi laten (hikmah) disebabkan ia bukan aturan yang muncul dari realitas sosial kemasyarakatan.

Para tokoh agama Masyarakat KPMSB dan KKST sejak dulu hingga saat ini sepakat mengenai realitas poligami. Beberapa tokoh agama yang bermazhab Syafi'i ataupun mazhab Hanafi memiliki pemikiran dan persepsi yang sama. Salah satu pandangan tokoh agama yang beraliran mazhab Syafi'i memiliki arah yang progresif. Pernyataan yang bahwa suami yang mempunyai empat istri dan salah satunya ditalak raji', maka laki-laki itu tidak bisa melakukan akad nikah dengan perempuan lain. Jika ingin menikah, istri yang yang ditalak tersebut harus sudah habis masa iddahnya. Akan tetapi, jika suami mentalak istrinya tersebut talak ba'in, maka ia boleh langsung nikah dengan perempuan lainnya. Bahkan ia juga boleh nikah dengan saudara perempuan istrinya -yang ditalak ba'in- sekalipun masih masa iddah sebab suaminya melalui talak ba'in telah mengakhiri -atau memutuskan- status pernikahan dan relasi suami istri. Ada pula tokoh agama yang memiliki pandangan berbeda bahwa seorang suami tidak boleh nikah dengan wanita lain -pada konteks ini adalah perempuan yang kelima-, sebelum istri yang diceraikan tersebut habis masa iddahnya. Pola yang ini menurut para tokoh agama tersebut tanpa ada pembedaan antara istri yang ditalak raji' atau talak ba'in. Dengan demikian, masingmasing para tokoh agama di Masyarakat KPMSB dan KKST melalui dalil-dalil yang bersumber dari al-Qur'an dan hadis memunculkan argumentasi yang membenarkan dan mengukuhkan poligami. Namun, Imam Syafi'i membatasi realitas poligami dengan landasan keadilan, seperti yang disimpulkan dalam riset Rifqi, $\mathrm{dkk}^{45}$

\section{Dimensi Laten Poligami: Komparasi dalam Islam dan Masyarakat}

Secara kuantitas, jumlah istri yang boleh dikawini oleh seorang laki-laki hanya sampai empat istri. Artinya, batasan jumlah yang tidak lebih dari angkat empat merupakan jumlah yang diharamkan. Keterangan "batasan kuantitatif” ini dapat dilihat dalam QS. an-Nisa' ayat 3 pada partikel kata "maśnā wa śulàs̄ā wa rubā'a" dan juga hadis-hadis nabi Muhammad seperti yang diriwayatkan oleh al-Tirmidzi tersebut -hadis ini telah disepakati para sahabat dan mujtahid meskipun masa hidup mereka berbeda-beda. Secara sosiologis dan teologis, Masyarakat KPMSB dan KKST cenderung berpoligami jika memiliki syarat seperti: pertama, tidak menjadi penyebab kehancuran keluarga, kesucian dan kebaikan benar-benar harus dijaga; kedua, jumlah istri tidak lebih empat orang; mereka memiliki komitmen jika pernikahan dengan istri kelima -baca perkawinan dengan perempuan yang kelima- tidak sesuai sunnah.

Ketiga, mampu bersikap adil terhadap semua istri dalam urusan material (lahiriah) dan keadilan dalam beragi perasaan cinta disesuaikan dengan kemampuan mereka masing-masing suami. Mereka meyakini jika rasa cinta merupakan perasaan yang diluar batas kemampuan manusia agar mampu menguasainya. Landasan yang menjadi prioritas dan tuntutan dalam konteks ini adalah sikap yang menunjukkan asas keadilan-syarat yang wajib dipenuhi, kesimpulan

${ }_{45}$ Muhammad Mualimur Rifqi and et.al, "Keadilan Dalam Poligami Perspektif Madzab Syafi'i," Hikmatina: Jurnal Ilmiah Hukum Keluarga Islam 1, no. 2 (2019): 86-92. 
riset Syam \& Syachrofi. ${ }^{46}$ Sikap kecenderungan berat sebelah kepada satu istri, sehingga istri yang lain menjadi terkatung-katung; hal ini yang diharamkan; dan yang keempat, kemampuan Masyarakat KPMSB dan KKST memberi nafkah. Walaupun kemampuan ini merupakan syarat tambahan menurut Imam Syafi'i; ada pula yang mengatakan sebagai syarat dinayah dan bukan sebagai syarat qadhi (keputusan pengadilan).

Berkaitan dengan syarat-syarat tersebut, Masyarakat KPMSB dan KKST sangat memprioritaskan dan meneguhkan pada syarat keadilan. Berlaku adil kepada semua istri seperti aspek makan, tempat tinggal, pakaian dan urusan kebendaan lainnya merupakan keharusan. Masyarakat KPMSB dan KKST sepakat, jika realitas poligami perlu diterjemahkan dalam sikap tanpa membedakan istri yang kaya atau miskin, cantik atau jelek, dan putih atau hitam. Sikap yang mencerminkan keadilan inilah diasumsikan memunculkan keberkahan dan ke-sakinah-an keluarga. Dari keyakinan inilah, Masyarakat KPMSB dan KKST cenderung untuk menikah dengan pola berpoligami. Dan mengenai meminta persetujuan dari istri sebelumnya bukan merupakan syarat sahnya akad pernikahan, melainkan syarat sah akad nikah perspektif Undang-Undang No. 1 Tahun 1974 Tentang Perkawinan. Tetapi pada konteks ini ada kalangan akademisi yang mempunyai pandangan berbeda dalam kesimpulan riset. Kesimpulan salah satu riset Munawar ini menyatakan bahwa perlu ada keadilan hukum terhadap pelaku penikahan poligami tanpa seizin izin -dalam hal ini ada peran peradilan. ${ }^{47}$

Berdasarkan deskripsi tersebut tampak jelas dan tidak memunculkan rasa skeptis bahwa ketika Islam mensyari'atkan pernikahan dengan sistem poligami telah membawa hikmah dan nilai kemanfaatan universal. Konteks ini bisa dilihat dari dimensi yang dimunculkannya seperti kemaslahatan yang bersifat sosial maupun personal. Semua dimensi ini bertujuan mengentaskan problematika sosial dan menyelamatkan umat manusia dari dekadensi moral. Artinya, syari'ah poligami oleh Tuhan kepada manusia dan manfaatnya untuk manusia juga. Kesimpulan riset Khalik pada konteks ini bisa dikatakan ada keselarasan. Kesimpulan riset itu menyatakan, jika manusia bertanggung jawab atas perbuatannya, maka poligami perlu memunculkan keadilan. ${ }^{48}$ Salah satu dimensi laten (hikmah) yang ada dalam realitas poligami, antara lain: pertama, manfaat sosial; ketidakseimbangan kuantitas perbandingan antara laki-laki dan perempuan. Hal ini diakibat oleh beberapa aspek seperti perang dunia yang berkepanjangan, bencana alam dan wabah penyakit yang menyebabkan kematian pada manusia berjenis kelamin laki-laki. Oleh sebab itu, realitas poligami bisa untuk mengatasi ketimpangan tersebut melalui pola satu banding empat. Pesan inilah yang sesuai dengan kesimpulan riset Simamora bahwa ayat poligami tafsirnya perlu melihat konteksnya. Artinya, ayat-ayat poligami tersebut perlu mempertimbangkan situasi dan kondisi psikologis masyarakat, antropologis, kultural, dan sosial. ${ }^{49}$

Dan yang kedua, manfaat individu; yang hakikatnya berdasarkan pada nilai-nilai kemaslahatan diri seseorang. Artinya, poligami diharapkan mampu meningkatkan ke-sakinahan dalam pernikahan hingga berdampak pada kebahagiaan diri. Riset Zuhra yang memfokuskan

\footnotetext{
${ }_{46}$ Masiyan M. Syam \& Muhammad Syachrofi, "Hadis-Hadis Poligami: Aplikasi Metode Pemahaman Hadis Muhammad AlGhazali,” Diroyah: Jurnal Ilmu Hadis 4, no. 1 (2019): 89-98.

47 Abdul Eko Munawar, "Nikah Siri Dan Poligami: Antara Kesadaran Sosial Keagamaan Dan Benturan Perundang-Undangan," Jurnal Hukum Islam 7, no. 1 (2019): 20-39.

48 Subehan Khalik, “Menakar Teologi Keadilan Dalam Poligami,” Ar-Risalah:Jurnal Ilmu Syariah Dan Hukum 19, no. 1 (2019): 57-66.

49 Nur Aisah Simamora, "Menguji Keberterimaan Pemikiran Tentang 'Monogami Sebagai Syarat Tak Tertulis Saat Pernikahan Berlangsung' Menurut Para Ahli Hukum Islam Di Sumatera Utara,” Jurnal Penelitian Medan Agama 10, no. 1 (2019): 115-39.
} 
pada problematika pernikahan yang berpola poligami perspektif perundang-undangan, sehingga muncul persyaratan-persyaratan yang perlu dipenuhi untuk berpoligami. ${ }^{50}$ Bentuk problematikanya seperti istri yang tidak bisa memberikan keturunan (mandul) akan menjadi masalah besar dalam rumah tangga. Dalam kasus ini pilihan suami adalah menceraikan istri tersebut atau ia menikah lagi dengan perempuan lain. Bagi istri yang memiliki pengertian, maka ia akan merelakan suami mereka memiliki penikahan poligami daripada perceraian. Begitu pula dengan istri yang berpenyakit kronis -bahkan tidak sembuh-sembuh dalam waktu yang panjang-, maka problematika ini memiliki kesamaan seperti istri yang mandul.

Bahkan ada pula problematika kemasyarakatan yang menuntun pada realitas poligami yaitu ketika suami bertugas di tempat yang jauh dan dalam waktu lama. Sementara anak dan isrti tidak mungkin dibawa serta dalam tugasnya tersebut. Dalam kasus seperti ini seorang suami akan berhadapan dengan dua pilihan. Pertama; mungkin suami akan memuaskan kebutuhan bilogisnya melalui hubungan yang tidak sah atau dengan wanita yang bukan istrinya; dan kedua; dalam keadaan bertugas itu suami akan menikah lagi. Maka pilihan kedua ini lebih terhormat dari pada kemungkinan suami akan berbuat zina.

Ada pula sosok laki-laki -baca seorang suami- yang mempunyai hasrat seks yang tinggi (libido kuat). Dalam keadaan ini seorang suami mungkin tidak merasa puas ketika berhubungan dengan satu istri saja yang secara biologis telah lemah. Dalam konteks ini adalah istri yang sudah tua, lemah, sedang haid, nifas dan/atau sedang mengandung tua. Pada saat seperti ini suami tidak bisa menahan lama-lama gejolak seks atau hasrat libidonya. Maka bisa saja seorang suami melakukan poligami atau beristri lagi secara sah daripada melakukan hubungan tanpa ikatan pernikahan atau perzinaan.

\section{Penutup}

Berdasapkan pada deskripsi di atas dapat disimpulkan bahwa praktek realitas poligami muncul dan berakar kuat disebabkan dukungan budaya masyarakat oligarkis-patriarkis yang memposisikan laki-laki sebagai patron bagi perempuan. Posisi ini yang mendorong tumbuh kembangnya praktek pernikahan poligami di kalangan para elit masyarakat KPMSB dan KKST. Mereka sendiri pun walaupun lebih condong pada nilai operasional etis, yaitu: nilai keadilan, egaliter, dan humanis, tetapi budaya tersebut memposisikan perempuan berada di bawah laki-laki.

Di sisi yang lain, elit masyarakat KPMSB dan KKST memilih pernikahan poligami tidak lepas dari nilai-nilai teologis yang diyakininya. Artinya, elit masyarakat KPMSB dan KKST yang memeluk agama Islam mempunyai keyakinan jika pernikahan dengan pola poligami tidak menyalahi nilai-nilai teologis Islam. Bahkan berdasarkan penafsiran terhadap QS. an-Nisa' ayat 3 memang Islam membuka ruang bagi laki-laki untuk melakukan pernikahan poligami. Partikel kata "satu saja" ( $f a$ wāhidah) dalam ayat tersebut nyatanya bukan bentuk larangan untuk berpoligami, justru ia merupakan suatu tuntunan untuk menambah satu lagi selain istri pertama jika tidak mampu berbuat adil. Makna keadlian pun pada konteks ini lebih bersifat material, sehingga laki-laki yang mampu berlaku adil secara materi dapat melakukan pernikahan dengan pola poligami sampai jumlah empat istri. Praktek penikahan poligami pun akhirnya tidak tabu dilakukan laki-laki masyarakat KPMSB dan KKST.

50 Fatimah Zuhrah, "Problematika Hukum Poligami Di Indonesia: Analisis Terhadap UU No. 1 Tahun 1974 Dan KHI," Al-Usrah: Jurnal Al-Ahwal as-Syakhsiyah 5, no. 1 (2017): 27-41. 


\section{DAFTAR PUSTAKA}

Abd. Karim. “Sibali Parri: Andi Depu Dalam Gerakan Revolusi Di Mandar 1942-1946.” Tebar Science: Jurnal Kajian Sosial \& Budaya 2, no. 2 (2018): 15-27.

Abdul Eko Munawar. "Nikah Siri Dan Poligami: Antara Kesadaran Sosial Keagamaan Dan Benturan Perundang-Undangan.” Jurnal Hukum Islam 7, no. 1 (2019): 20-39.

Abdullah Nashih Ulwan. Bahagia Nabi Bersama Istri-Istrinya. Yogyakarta: Absolut, 2002.

Abduttawab Haikal. Rahasia Perkawinan Rasulullah SAW: Poligami Dalam Islam vs Monogami Barat. Edited by Ilyas Isma'il al-Sendany. Jakarta: CV. Pedoman Ilmu Jaya, 1993.

Abu Ameenah Bilal Philips \& Jamila Jones. Polygamy in Islam. Riyadh: International Islamic Publishing House, 1994.

Abu Isa Muhammad bin Saurah al-Tirmidzi. Sunan Al-Tirmidzi. Beirut: Dar al-Fikir, 1980.

Agus Sunaryo. "Poligami Di Indonesia: Sebuah Analisis Normatif-Sosiologis." Yin Yang: Jurnal Studi Gender \& Anak 5, no. 1 (2010): 143-67.

Alamgir, Aurangzaib. "Islam and Polygamy: A Case Study in Malaysia." Procedia: Social and Behavioral Sciences 114, no. 1 (2014): 889-93.

Alean al-Krenawi. "Women of Polygamous Marriages in Primary Health Care Centers." Contemporary Family Therapy 21, no. 3 (1999): 417-30.

Ali, Jawwad. Sejarah Arab Sebelum Islam: Kondisi Sosial-Budaya. Edited by M. Yusni Amru \& Moh. Ali. 4th ed. Jakarta: Alvabet, 2019.

Ambar, Iriani. "Menelisik Pesan Moral Di Balik Poligami: Deskripsi Historis Kehidupan Muhammad SAW Dan Implikasinya Dalam Islam." Jurnal Al-Maiyyah 8, no. 1 (2015): 120-34.

Asiyah, Siti, and et.al. "Konsep Poligami Dalam Al-Qur'an: Studi Tafsir Al-Misbah Karya M. Quraish Shihab." Fikri: Jurnal Kajian Agama, Sosial Dan Budaya 4, no. 1 (2019): 85-100.

Azwarfajri. “Keadilan Berpoligami Dalam Perspektif Psikologi.” Jurnal Substantia 13, no. 2 (2011): 16171.

Christian Pelras. Manusia Bugis. Jakarta: Nalar, 2006.

Dissa, Yaya. "Polygamy in Mali: Social and Economic Implications on Families." International Journal of African and Asian Studies 27, no. 1 (2016): 94-107.

Ertan Yilmaz \& Lut Tamam. "The Relationship Between Polygamy and Psychiatric Disorder in Turkish Women,." International Journal of Social Psychiatry 64, no. 8 (2018): 821-27.

Fatimah Zuhrah. "Problematika Hukum Poligami Di Indonesia: Analisis Terhadap UU No. 1 Tahun 1974 Dan KHI." Al-Usrah: Jurnal Al-Ahwal as-Syakhsiyah 5, no. 1 (2017): 27-41.

Flora, Tsoaledi Daniel Thobejane \& Takayindisa. "An Exploration of Polygamous Marriages: A Worldview." Mediterranean Journal of Social Sciences 5, no. 27 (2014): 1058-66.

Haris Hidayatulloh. “Adil Dalam Poligami Perspektif Ibnu Hazm.” Religi: Jurnal Studi Islam 6, no. 2 (2015): 207-36.

Hasyim, Syafiq. Hal-Hal Yang Tak Terpikirkan Tentang Isu-Isu Keperempuanan Dalam Islam: Sebuah Dokumentasi. Bandung: Mizan, 2001.

Hendri, Ali. "Poligami Perspektif Kitab Al-Tafsir Al-Wasit Li Al-Qur'an Al-Karim.” Al-Bayan: Jurnal Studi Al-Qur'an Dan Tafsir 3, no. 1 (2018): 51-61. 
Hikmah, Siti. “Fakta Poligami Sebagai Bentuk Kekerasan Terhadap Perempuan.” Sawwa: Jurnal Studi Gender 7, no. 2 (2012): 1-20.

Khadijah Tukur Batagarawa \& Atiku Garba Yahaya. "Counting Blessings with Cautions: Wisdom and Vitality of Polygamy in Islam." IOSR: Journal of Humanities and Social Science 23, no. 9 (2018): 47-53.

Mahridha. "Poligami Dalam Kajian Hukum Islam: Studi Analisis Pandangan Hasbi Ash-Shiddiegy." Jurisprudensi: Jurnal Ilmu Syari'ah, Perundang-Undangan Dan Ekonomi Islam 9, no. 2 (2017): 50-78.

Makrum. "Poligami Dalam Perspektif Al-Qur'an." Maghza: Jurnal Ilmu Al-Qur'an Dan Tafsir 1, no. 2 (2016): 35-50.

Marzuki. "Poligami Dalam Hukum Islam.” Jurnal Civics: Media Kajian Kewarganegaraan 2, no. 2 (2005): $1-10$.

Masiyan M. Syam \& Muhammad Syachrofi. "Hadis-Hadis Poligami: Aplikasi Metode Pemahaman Hadis Muhammad Al-Ghazali.” Diroyah: Jurnal Ilmu Hadis 4, no. 1 (2019): 89-98.

Moqsith, Abd. “Tafsir Atas Poligami Dalam Al-Qur'an.” Karsa: Journal of Social and Islamic Culture 23, no. 1 (2015): 133-49.

Muhammad Arif Mustofa. "Poligami Dalam Hukum Agama Dan Negara.” Al-Imarah:Jurnal Pemerintahan Dan Politik Islam 2, no. 1 (2005): 47-58.

Muhammad Mualimur Rifqi, and et.al. "Keadilan Dalam Poligami Perspektif Madzab Syafi'i." Hikmatina: Jurnal Ilmiah Hukum Keluarga Islam 1, no. 2 (2019): 86-92.

Mukri, Moh. “Poligami: Antara Teks Dan Konteks Sosial.” Al-'Adalah 14, no. 1 (2017): 201-24.

Nur Aisah Simamora. "Menguji Keberterimaan Pemikiran Tentang 'Monogami Sebagai Syarat Tak Tertulis Saat Pernikahan Berlangsung' Menurut Para Ahli Hukum Islam Di Sumatera Utara." Jurnal Penelitian Medan Agama 10, no. 1 (2019): 115-39.

Nurmila, Nina. Women, Islam and Everyday Life: Renegotiating Polygamy in Indonesia. London: Routledge, 2009.

Rarasrum Dyah Kasitowati. "Sandeq Dan Roppo: Kearifan Lokal Suku Mandar Pesisir, Sulawesi Barat." Sabda: Jurnal Kajian Kebudayaan 6, no. 1 (2011): 63-68.

Rike Luluk Khoiriah. "Poligami Nabi Muhmmad Menjadi Alasan Legitimasi Bagi Umatnya Serta Tanggapannya Kaum Orientalis.” Jurnal Living Hadis 3, no. 1 (2018): 1-21.

Riyandi S. "Syarat Adanya Persetujuan Istri Untuk Berpoligami: Analisis Fikih Syafi'iyyah Terhadap Undang-Undang Perkawinan Nomor 1 Tahun 1974." Jurnal Ilmiah Islam Futura 15, no. 1 (2015): 111-42.

Rohmansyah. "Analisa Pendekatan Bahasa Dan Historis Terhadap Poligami Dalam Hadist Nabi." Kalimah: Jurnal Studi Agama Dan Pemikiran Islam 17, no. 1 (2019): 55-70.

Sa'adah, Nuru, and et.al. "Poligami Dalam Lintas Budaya Dan Agama: Meta-Interpretation Approach." Asy-Syir'ah:Jurnal Ilmu Syari'ah Dan Hukum 49, no. 2 (2015): 479-99.

Sastri Sunarti. “Kosmologi Laut Dalam Tradisi Lisan Orang Mandar Di Sulawesi Barat.” Aksara 29, no. 1 (2017): 33-48.

Shihab, Quraish. Wawasan Al-Qur'an: Tafsir Maudhu'i Atas Pelbagai Persoalan Umat. Bandung: Mizan, 2004. 
Subehan Khalik. "Menakar Teologi Keadilan Dalam Poligami." Ar-Risalah: Jurnal Ilmu Syariah Dan Hukum 19, no. 1 (2019): 57-66.

Wahid Syarifuddin Ahmad. "Status Poligami Dalam Hukum Islam: Telaah Atas Berbagai Kesalahan Memahami Nas Dan Praktik Poligami." Al-Ahwal: Jurnal Hukum Keluarga Islam 6, no. 1 (2013): $57-70$.

Yufni Faisol. "Konsep Adil Dalam Poligami: Telaah Pemikiran Mushthofa Al-'Adawi Dalam Tafsir AlTashil Lita'Wil Al-Tanzil.” International Journal Ihya' Ulum Al-Din 18, no. 1 (2016): 25-47.

Zuhrah, Fatimah. "Problems of Polygamy in Indonesia: Analysis of Law No. 1 of 1974 and KHI." Journal of Islam and Scince 5, no. 1 (2016): 1-17. 